\title{
Molecular characterization of pathogenic Escherichia coli isolated from diarrheic and in-contact cattle and buffalo calves
}

\author{
Walid S. Awad ${ }^{1} \cdot$ Amr A. El-Sayed $^{1,2}$ • Faten F. Mohammed ${ }^{3} \cdot$ Noha M. Bakry $^{1} \cdot$ Nadra-Elwgoud M. I. Abdou $^{1}$. \\ Mohamed S. Kamel ${ }^{1,2}$
}

Received: 3 June 2019 / Accepted: 2 July 2020 / Published online: 10 July 2020

(C) Springer Nature B.V. 2020

\begin{abstract}
Escherichia coli field isolates from calves were characterized and categorized into the most significant diarrheagenic pathotypes using polymerase chain reaction (PCR) assays with different specific primers. The used PCR systems were designed to detect sequences representing the group-specific virulence genes encoding fimbriae $f 5(K 99)$, Shiga toxins $\left(s t x_{1}\right.$ and $\left.s t x_{2}\right)$, heat-stable enterotoxins ( $(s t)$, heat-labile enterotoxins $(l t)$, intimin (eae), hemolysin (hylA), and EAEC heat-stable enterotoxin (astA). In the present work, a total of $150 \mathrm{E}$. coli field isolates were recovered from 150 fecal swabs collected from 100 diarrheic and 50 apparently healthy in-contact cattle and buffalo calves under 3 months old. Out of these 150 isolated E. coli, 106 isolates from 77 diarrheic and 29 in-contact calves harbored one or more of the investigated virulence genes. The pathotyping of the isolates could classify them into shigatoxigenic E. coli (STEC), enteropathogenic E. coli (EPEC), enterotoxigenic E. coli (ETEC), and enteroaggregative E. coli (EAEC) with a 30.7, 2.7, 12.7, and 7.3\% distribution, respectively. Meanwhile, the detection rates of $f 5, s t x_{1}, s t x_{2}, s t, l t, e a e, h y l A$, and astA genes were 17.3, 27.3, 6.7, 10,37.3, 17.7, 9.3, and 20.7\%, respectively. These virulence genes were found either single or in different combinations, such as $s t x / e a e, s t x / s t / f 5$, eae/st/f5, or $s t / l t / f 5$. Four attaching-effacing shigatoxigenic E. coli isolates (AE-STEC) harboring stx/eae were retrieved from diarrheic calves. Although none of the stx-or eae-positive isolates was verified as $\mathrm{O} 157: \mathrm{H} 7$, STEC isolates detected in apparently healthy calves have potential pathogenicity to humans highlighting their zoonotic importance as reservoirs. Atypical combinations of ETEC/STEC and ETEC/EPEC were also detected in percentages of 14.7 and $2.7 \%$, respectively. Most of these atypical combinations were found more in buffalo calves than in cattle calves. While STEC and EPEC isolates were detected more in cattle calves than in buffalo calves, ETEC isolates were the same in the two species. The pathogenic $E$. coli infection in calves was recorded to be higher in the first weeks of life with the largest numbers of virulence factor-positive isolates detected at the age of 4 weeks. Histopathological examination of five intestinal samples collected from four dead buffalo calves revealed typical attaching and effacing (AE) lesion which was correlated with the presence of intimin encoding virulence gene (eae). Other lesions characterized by hemorrhagic enteritis, shortening and fusion of intestinal villi and desquamation of the lining epithelium of intestinal mucosa had also been detected.
\end{abstract}

Keywords Diarrhea $\cdot$ Calves $\cdot$ E. coli $\cdot$ Virulence gene profiles $\cdot$ Multiplex PCR $\cdot$ Histopathology $\cdot$ Pathotypes

\section{Introduction}

Escherichia coli has been implicated as a significant infec-

Mohamed S. Kamel

m_salah@staff.cu.edu.eg

1 Department of Medicine and Infectious Diseases, Faculty of Veterinary Medicine, Cairo University, Cairo, Egypt

2 Laboratory of Molecular Epidemiology (LME), Faculty of Veterinary Medicine, Cairo University, Cairo, Egypt

3 Department of Pathology, Faculty of Veterinary Medicine, Cairo University, Cairo, Egypt tious cause of neonatal calf diarrhea (NCD) (Nguyen et al. 2011), which is considered one of the most important problems in young calves provoking great economic losses, including high morbidity and mortality rates, diminished growth rate, high treatment costs, and time wasted for caring the diseased calves (Ok et al. 2009).

Several E. coli pathotypes are involved in NCD according to their attributes of virulence as enterotoxigenic (ETEC), enteropathogenic (EPEC), shigatoxigenic (STEC) which 
include subgroup enterohemorrhagic (EHEC), enteroinvasive (EIEC), enteroaggregative (EAEC), and enteroadherent E. coli (EAdEC) (Nagy and Fekete 2005; Andrade et al. 2012).

In the past, the ETEC pathotype was considered as the significant inducer of calf diarrhea, especially in the first 4 days of life (Nagy and Fekete 2005; Nguyen et al. 2011; Andrade et al. 2012). Its pathogenicity is attributed to the expression of fimbrial antigens, such as F5, and the elaboration of one or more enterotoxins like heat-stable enterotoxins (ST) and heat-labile enterotoxins (LT) (Welch 2006). Later on, EPEC pathotype inducing attaching and effacing (AE) lesions on intestinal cells due to the production of the protein intimin (Eae) has been involved in young calf diarrhea and dysentery (Moxley and Smith 2010; Mainil and Fairbrother 2014). Intimin is required for producing intestinal AE lesions, which are depicted by intimate adherence of $E$. coli to the enterocyte, leading to obliteration of the brush border microvilli and destroying the gastric microvillus brush border (Franck et al. 1998; Nataro and Kaper 1998). The pathogenicity of the STEC pathotype is attributed to the production of Shiga toxins 1 and $2\left(\mathrm{Stx}_{1}\right.$ and $\left.\mathrm{Stx}_{2}\right)$ which had been implicated in calf diarrhea, although they are harbored in the intestines of both healthy and diarrheic calves (Sandhu and Gyles 2002; Constable et al. 2017). A highly virulent strain of STEC, enterohemorrhagic E. coli (EHEC), harbors several genes coding for shigatoxins (Stx1 and Stx2), the protein intimin (Eae), and the plasmid encoding E. coli hemolysin (HlyA) (Law 2000; Kamel et al. 2015). This pathotype is associated with severe clinical signs in humans characterized by hemorrhagic colitis and hemolytic uremic syndrome (DebRoy and Maddox 2001). EHEC strains from animals that produce Shiga toxins and induce AE lesions are termed AESTEC (Piérard et al. 2012; Fakih et al. 2017; Thiry et al. 2017).

Molecular characterization of pathogenic E. coli based on the presence of virulence markers is important for the differentiation of $E$. coli pathotypes by means on the widely used multiplex PCR (Vidal et al. 2005; Müller et al. 2007; Nguyen et al. 2011).

In this study, pathotyping of $E$. coli isolates recovered from diarrheic and in-contact cattle and buffalo calves in Egypt was performed using polymerase chain reaction (PCR) assays with different specific primers. Our study also aimed to investigate virulence gene profile combination in different pathotypes and characterize the pathogenic effect of $E$. coli through a bacteriological and histopathological examination of small and large intestines collected from dead diarrheic buffalo calves infected with $E$. coli. This study also aimed to track the different circulating $E$. coli pathotypes harboring various virulence genes combinations as it is simple for $E$. coli to exchange virulence genes with other Enterobacteriaceae members evolving new strains.

\section{Materials and methods}

\section{Sample collection}

A total of 150 fecal swabs were collected from 100 diarrheic cattle and buffalo calves (51 and 49, respectively) and 50 incontact cattle and buffalo calves (19 and 31, respectively) from different herds in the Nile Delta (Table 1). The age of the investigated calves ranged from one day up to 3 months. Based on their age, the calves were divided into 3 groups (up to 4 weeks, 4-8 weeks, and 8-12 weeks). Fecal swabs were directly collected from the rectum of the examined calves via sterile cotton swabs. The swabs were inserted into the upper third of the Amies transport media (Oxoid, UK) and afterwards kept at $4{ }^{\circ} \mathrm{C}$ till bacteriological examination.

Five intestinal samples (two small intestine samples from two dead calves, one large intestine sample from another one dead calf, and the last dead calf had two samples, one small intestine and the other from the large intestine) were collected from four buffalo calves up to one month old died suffering from diarrhea. Intestines at postmortem examination showed congestion and distention of intestinal loops with presence of hemorrhagic fluid content. Each intestinal sample was divided into two parts; one part was preserved in $10 \%$ formol saline for histopathological examination and the second part was used for bacteriological isolation and identification.

\section{Isolation of $E$. coli}

Fecal swabs and intestinal samples were inoculated into Trypticase soya broth (Oxoid, UK) and incubated for $24 \mathrm{~h}$ at $37^{\circ} \mathrm{C}$ for $E$. coli propagation. The enriched samples were streaked on MacConkey and Eosin Methylene Blue (EMB) agar media (Oxoid, UK) in the meantime and incubated at $37{ }^{\circ} \mathrm{C}$ for $24 \mathrm{~h}$. Metallic sheen colonies on EMB agar with lactose fermenting capabilities on MacConkey agar were biochemically identified using Simmon's citrate and triple sugar iron (TSI) agar media (Oxoid, UK).

\section{DNA extraction from the obtained $E$. coli isolates}

Bacterial DNA extraction was performed using the boiling method (Wani et al. 2003; Bhat et al. 2008). Briefly, single colonies were inoculated into BHI broth at $37{ }^{\circ} \mathrm{C}$ overnight. From which, $1.5 \mathrm{~mL}$ inoculated broth was centrifuged for $10 \mathrm{~min}$ at $1200 \times \mathrm{g}$. The pellet harboring the bacteria was resuspended in $150 \mu \mathrm{L}$ of sterile distilled water. The bacteria were then subjected to lysis via boiling in a water bath for $10 \mathrm{~min}$. Afterwards, the lysate was subjected to a centrifugation step again to get rid of cellular debris. The supernatant containing bacterial DNA was exploited as a DNA template for PCR. 
Table 1 Geographical distribution of diarrheic and apparently healthy in-contact cattle and buffalo calves

\begin{tabular}{|c|c|c|c|c|c|c|c|}
\hline \multirow[t]{2}{*}{ Animal locality } & \multicolumn{3}{|c|}{ Diarrheic calves } & \multicolumn{3}{|c|}{ In-contact calves } & \multirow[t]{2}{*}{ Total } \\
\hline & Cattle & Buffalo & Total & Cattle & Buffalo & Total & \\
\hline Giza governorate & 20 & 46 & 66 & 6 & 31 & 37 & 103 \\
\hline Gharbiya governorate & 6 & - & 6 & 13 & - & 13 & 19 \\
\hline Cairo-Alex D.R. & 25 & 3 & 28 & - & - & - & 28 \\
\hline Total & 51 & 49 & 100 & 19 & 31 & 50 & 150 \\
\hline
\end{tabular}

\section{Molecular identification of $E$. coli isolates using PCR}

The highly conserved 16S rRNA gene was selected for the molecular detection of $E$. coli isolates according to Wang et al. 2002 (Table 2). DNA amplification was accomplished in a total $25 \mu \mathrm{L}$ mixture volume, including $5 \mu \mathrm{L}$ of DNA template, $5 \mu \mathrm{L}$ of $5 \times$ Taq Master mix (Jena Bioscience, Germany), $1 \mu \mathrm{L}$ of $16 \mathrm{~S}$ rRNA forward and reverse primers $(10 \mathrm{pmol} / \mu \mathrm{L})$, and $13 \mu \mathrm{L}$ PCR-grade water (Jena Bioscience, Germany). Samples were subjugated to initial denaturation for $5 \mathrm{~min}$ at $94{ }^{\circ} \mathrm{C}$ followed by 35 cycles of denaturation $\left(94^{\circ} \mathrm{C}, 30 \mathrm{~s}\right)$, annealing $\left(62{ }^{\circ} \mathrm{C}, 30 \mathrm{~s}\right)$, and elongation $\left(72{ }^{\circ} \mathrm{C}, 1 \mathrm{~min}\right)$. These cycles were followed by a single elongation step ( $5 \mathrm{~min}$ at $72{ }^{\circ} \mathrm{C}$ ). E. coli serogroup O6 biotype 1 (ATCC $® 25922^{\mathrm{TM}}$ ) reference strain and PCR-grade water were utilized as positive controls for the 16S rRNA gene of E. coli and negative controls, respectively. The amplified products were separated by electrophoresis through $1.5 \%$ agarose ( $\mathrm{wt} / \mathrm{vol})$, stained with $0.5 \mu \mathrm{g} / \mathrm{mL}$ ethidium bromide, visualized under UV illumination, imaged with a GelDoc 1000 fluorescent imaging system (Bio-Rad) and analyzed by Gel-pro analyzer ${ }^{\circledR}$ version 4 (Media Cybernetics, Silver Spring, MD, USA).

\section{Determination of virulence gene profile}

For virulence gene detection ( $f 5$, st, lt, eae, stx $1, s t x_{2}$, hylA, and astA), three PCR systems with three different primer sets and different reaction conditions as shown in Tables 2 and 3 were performed using a T-Personal thermal cycler (Biometra, Germany). As a positive control for $s t x_{1}, s t x_{2}$, hylA, and eae genes, the E. coli serogroup O157 (ATCC@700927 ${ }^{\mathrm{TM}}$ ) reference strain was used, while the E. coli standard serotype O101: F5 reference strain was used as a positive control for $f 5$ and $s t$ genes.

\section{Histopathological examination}

Five tissue specimens collected from dead calves were fixed in $10 \%$ formol saline, dehydrated in ethyl alcohol, cleared in xylene, and embedded in paraffin wax. Tissue paraffin sections of $5 \mu \mathrm{m}$ thickness were obtained and stained by hematoxylin and eosin for microscopic examination of pathological lesions (Luna 1968).

\section{Statistical analysis}

Statistical analyses were accomplished using SPSS 22.0 (IBM, USA). The obtained data were analyzed by the chisquare test for evaluating the association and significance between variables. A $P$ value $<0.05$ is deemed significant.

\section{Results}

A total number of $150 \mathrm{E}$. coli isolates were detected and identified via biochemical and molecular assays employing PCR targeting the E. coli-specific 16s rRNA gene (Fig. 1a). Different multiplex and singleplex PCR assays were implemented to determine the harbored virulence genes of pathogenic E. coli as $s t x_{1}$, eae, hylA, and astA (Fig. 1b), stx 2 (Fig. 1c), and f5, st, and $l t$ (Fig. 1d). Out of 150 isolated E. coli, 106 $(70.7 \%)$ isolates from 77 diarrheic and 29 in-contact calves harbored at least one virulence gene, namely $s t x_{1}, s t x_{2}$, eae, hylA, astA, f5, st, and $l t$ (from buffalo calves only) in 37.3, $17.7,10,9.3,20.7,17.3,27.3$, and $6.7 \%$, respectively. On the other hand, $29.3 \%$ of the obtained isolates were considered non-pathogenic, based on the absence of the studied genes in these isolates. The virulence gene profile showed that the most common virulence gene combinations within STEC isolates was stx 1 and the AE-STEC that was detected in 4 E. coli isolates harboring stx/eae/hylA combinations. EAST-1 encoding gene (ast) was also detected as a single virulence gene in 11 isolates (EAEC) and as an additional gene in 20 isolates of various $E$. coli pathotypes, as shown in Table 4. The highest spectrum of virulence gene combinations of ETEC was $f 5 / s t$. Different combinations of virulence genes of STEC and ETEC were detected in 22 isolated $E$. coli with a predominant gene profile of $f 5 / s t / s t x$, as shown in Table 4 .

Based on virulence gene characterization, $E$. coli isolates were classified into pathotypes as STEC (30.7\%), ETEC (12.7\%), EAEC (7.3\%), and EPEC (2.7\%). In addition, mixed pathotypes, such as ETEC/STEC (14.7\%) and ETEC/EPEC (2.7\%), were also identified (Table 5). The ETEC, EPEC, 
Table 2 Primer names, target genes, oligonucleotide sequences, and the product size used in PCR

\begin{tabular}{|c|c|c|c|c|}
\hline Pathotype & Primer name (target gene) & Oligonucleotide sequences $\left(5^{\prime}-3^{\prime}\right)$ & Product size (bp) & References \\
\hline \multicolumn{5}{|c|}{ For molecular identification of $E$. coli } \\
\hline & E16S (16S rRNA) & $\begin{array}{l}\text { F: CCCCCTGGACGAAGACTGAC } \\
\text { R: ACCGCTGGCAACAAAGGATA }\end{array}$ & 401 & Wang et al. (2002) \\
\hline \multicolumn{5}{|c|}{ For detection of virulence factors encoding genes } \\
\hline EPEC & $\mathrm{EAE}(e a e)$ & $\begin{array}{l}\text { F: TCAATGCAGTTCCGTTATCAGTT } \\
\text { R: GTAAAGTCCGTTACCCCAACCTG }\end{array}$ & 482 & Vidal et al. (2005) \\
\hline \multirow[t]{3}{*}{ STEC } & Stx1 $\left(s t x_{1}\right)$ & $\begin{array}{l}\text { F: CGATGTTACGGTTTGTTACTGTGACAGC } \\
\text { R: AATGCCACGCTTCCCAGAATTG }\end{array}$ & 244 & Müller et al. (2007) \\
\hline & Stx2 $\left(s t x_{2}\right)$ & $\begin{array}{l}\text { F: CCATGACAACGGACAGCAGTT } \\
\text { R: CCTGTCAACTGAGCAGCACTTTG }\end{array}$ & 779 & $\begin{array}{l}\text { Gannon et al. (1992); } \\
\text { Kamel et al. (2015) }\end{array}$ \\
\hline & HlyA $(h l y A)$ & $\begin{array}{l}\text { F: AGCTGCAAGTGCGGGTCTG } \\
\text { R: TACGGGTTATGCCTGCAAGTTCAC }\end{array}$ & 569 & Wang et al. (2002) \\
\hline \multirow[t]{3}{*}{ ETEC } & $\mathrm{LT}(l t)$ & $\begin{array}{l}\text { F: GGCGACAGATTATACCGTGC } \\
\text { R: CGGTCTCTATATTCCCTGTT }\end{array}$ & 450 & Stacy-Phipps et al. (1995) \\
\hline & $\mathrm{ST}(s t)$ & $\begin{array}{l}\text { F: ATTTTTMTTTCTGTATTRTCTT } \\
\text { R: CACCCGGTACARGCAGGATT }\end{array}$ & 190 & \\
\hline & Fimbrial F5 (k99) & $\begin{array}{l}\text { F: TATTATCTTAGGTGGTATGG } \\
\text { R: GGTATCCTTTAGCAGCAGTATTTC }\end{array}$ & 314 & Franck et al. (1998) \\
\hline EAEC & EAST1 (astA) & $\begin{array}{l}\text { F: TGCCATCAACACAGTATATCCG } \\
\text { R: ACGGCTTTGTAGTCCTTCCAT }\end{array}$ & 102 & Müller et al. (2007) \\
\hline
\end{tabular}

EAEC, and ETEC/EPEC pathotypes were isolated at the highest rate from the 1 st 4 weeks old calves, while the highest rate of STEC pathotype was isolated from 4 to 8 weeks. The 3rd age group, from 8 to 12 weeks, was characterized by a higher rate of ETEC/STEC and absence of EPEC, ETEC, and ETEC/EPEC pathotypes (Fig. 2a,b). In opposite to age-based subgroups, there were no statistically significant differences between different $E$. coli pathotypes and animal sex (Fig. 3a,b). The influence of winter and summer seasons on the pathogenic $E$. coli prevalence in calves was investigated where their rate was found to be higher in the winter season (Fig. 3b).

Bacteriological and histopathological examinations of intestinal samples were characterized by congestion and distention of intestinal loops with the presence of hemorrhagic fluid content. These intestinal samples were bacteriologically positive for $E$. coli. Detection of $E$. coli virulence genes from intestinal isolates revealed the presence of gene encoding intimin (eae) in all isolates which was in charge of intestinal AE lesions. The histopathological data of the small intestine were in correlation with the results revealing shortening and fusion of intestinal villi (Fig. 4a) with desquamation of the lining epithelium and infiltration of leucocytes in the lamina propria (Fig. 4b,c). On the other hand, histopathological lesions in the large intestine were more severe than the small intestine. The histopathological alterations were characterized by massive necrosis of the intestinal mucosa (Fig. 4d) and vasculitis of the blood vessels in the submucosa (Fig. 4e). There were basophilic bacilli present in the necrotic mucosa and in the lamina propria (Fig. 4f).

\section{Discussion}

Despite the major progress in the cattle industry, neonatal diarrhea is still a major health problem causing high mortality and morbidity in young calves, leading to high economic losses (Constable et al. 2017). E. coli is the prominent bacterial cause of calf diarrhea (Radostits et al. 2007). Molecular characterization of pathogenic $E$. coli pathotypes and the harbored virulence gene profiles had been investigated using polymerase chain reaction (PCR) assays with different specific primers, and the pathological effect on calf intestines was analyzed to identify the virulence potentials of different $E$. coli pathotypes in cattle and buffalos.

As a normal gut inhabitant, it was expected to detect a reasonable percentage of non-pathogenic E. coli among the isolates. These isolates may be non-pathogenic, and the diarrheic animals may be affected by other infectious agents or these isolates might carry virulence genes not included in this study. The remaining $(70.7 \%)$ harbored at least one virulence gene, which was nearly similar to the results that detected pathogenic $E$. coli from diarrheic and apparently healthy calves at a percentage rate of 76.76 and $44.9 \%$ (Güler et al. 2008; Andrade et al. 2012).

The classification of different $E$. coli pathotypes depending on virulence gene distributions has been categorized into ETEC ( $f 5, s t$, and $l t)$, EPEC (eae), STEC (stx $x_{1}$ and $\left.s t x_{2}\right)$, AESTEC (stx $x_{1} s t x_{2}, e a e$, and hylA), and EAEC (astA). In this study, enterotoxigenic $E$. coli (ETEC) isolates represented $12.7 \%$ of isolated $E$. coli with a similar rate between cattle and buffalo calves. Comparable results were previously recorded the percentage rate of ETEC as 10 to $11 \%$ (Güler 
Table 3 Components and amplification PCR conditions utilized for detecting genes encoding virulence factors

\begin{tabular}{|c|c|c|c|}
\hline Genes encoding virulence factors & PCR components and volume $(\mu \mathrm{l})$ & PCR conditions & References \\
\hline eae, $h l y A, s t x_{1}$, and astA & $\begin{array}{l}5 \mu \mathrm{L} \text { Master Mix } \\
5 \mu \mathrm{L} \text { DNA template } \\
0.5 \mu \mathrm{L} \text { of each F\&R primer } \\
\quad(\text { with total } 4 \mu \mathrm{L} \text { ) } \\
11 \mu \mathrm{L} \text { PCR-grade water }\end{array}$ & $\begin{array}{l}\text { First condition } \\
1 \text { cycle }\left[94{ }^{\circ} \mathrm{C}, 5 \mathrm{~min}\right], 35 \text { cycles } \\
{\left[94{ }^{\circ} \mathrm{C}, 30 \mathrm{~s} / 62{ }^{\circ} \mathrm{C}, 30 \mathrm{~s} / 72{ }^{\circ} \mathrm{C}, 1 \mathrm{~min}\right]} \\
\text { and } 1 \text { cycle }\left[72{ }^{\circ} \mathrm{C}, 5 \mathrm{~min}\right]\end{array}$ & Chandra et al. (2013) \\
\hline$s t x_{2}$ & $\begin{array}{l}5 \mu \mathrm{L} \text { Master Mix } \\
5 \mu \mathrm{L} \text { DNA template } \\
13 \mu \mathrm{L} \text { PCR grade water } \\
1 \mu \mathrm{L} \text { of } \mathrm{F} \& \mathrm{R} \text { primers } \\
\quad \text { (with total } 2 \mu \mathrm{L} \text { ) }\end{array}$ & $\begin{array}{l}\text { Second condition } \\
1 \text { cycle }\left[95^{\circ} \mathrm{C}, 3 \mathrm{~min}\right], 35 \text { cycles } \\
{\left[95^{\circ} \mathrm{C}, 20 \mathrm{~s} / 58^{\circ} \mathrm{C}, 40 \mathrm{~s} / 72{ }^{\circ} \mathrm{C}, 90 \mathrm{~s}\right],} \\
\text { and } 1 \text { cycle }\left[72{ }^{\circ} \mathrm{C}, 5 \mathrm{~min}\right]\end{array}$ & $\begin{array}{l}\text { Gannon et al. (1992); } \\
\text { Kamel et al. (2015) }\end{array}$ \\
\hline$l t, s t$, and $f 5$ & $\begin{array}{l}5 \mu \mathrm{L} \text { Master Mix } \\
5 \mu \mathrm{L} \text { DNA template } \\
12 \mu \mathrm{L} \text { PCR-grade water } \\
0.5 \mu \mathrm{L} \text { of each } \mathrm{F} \& \mathrm{R} \text { primers } \\
\quad \text { (with total } 3 \mu \mathrm{L} \text { ) }\end{array}$ & $\begin{array}{l}\text { 3rd condition } \\
1 \text { cycle }\left[95^{\circ} \mathrm{C}, 5 \mathrm{~min}\right], 40 \text { cycles } \\
{\left[95^{\circ} \mathrm{C}, 45 \mathrm{~s} / 50{ }^{\circ} \mathrm{C}, 1 \mathrm{~min} / 72{ }^{\circ} \mathrm{C}, 1 \mathrm{~min}\right] \text {, }} \\
\text { and } 1 \text { cycle }\left[72{ }^{\circ} \mathrm{C}, 7 \mathrm{~min}\right]\end{array}$ & Aranda et al. (2004) \\
\hline
\end{tabular}

et al. 2008; Pourtaghi et al. 2015). On the contrary, a lower rate of ETEC was reported by Andrade et al. (2012) in Brazil, Borriello et al. (2012) in Italy, and Manzoor et al. (2015) in India.

All ETEC isolates were retrieved from diarrheic calves except one isolate originated from in-contact buffalo calf which may be in the incubation period. This was an indicator of the pathogenic effect of ETEC on calves causing diarrhea and agreed with Nagy and Fekete (2005) who mentioned that ETEC is the most common etiology of NCD. In this study, the most ETEC isolates from calves were F5 positive and produced ST toxins. The reason for this association is that both virulence genes are commonly encoded in the same plasmid (Osman et al. 2013; Ghanbarpour et al. 2017). The gene encoding heat-labile enterotoxin (lt) of ETEC could only be detected in buffalo calves $E$. coli isolates. This result was correlated with Borriello et al. (2012) who detected only the lt gene in ETEC isolates from water buffalo calves in Italy. The absence of $l t$ gene in cattle calves was mentioned in several studies by many authors (Nagy and Fekete 2005; Osman et al. 2013; Manzoor et al. 2015). The lack of LT toxin in cattle calves was not unexpected as LT toxin is assumed to be an atypical gene in bovine ETEC isolates (Woodward and Wray 1990).

The EPEC pathotype represented $2.7 \%$ of $E$. coli isolates and was found in diarrheic calves only which indicated that EPEC was a calf pathogen as mentioned by Moxley and Smith (2010). On the other hand, Foster and Smith (2009) claimed that the significance of EPEC as a calf pathogen is questionable, as can be found in both healthy and diarrheic calves. Lower frequency of EPEC was also mentioned by Güler et al. 2008 in Turkey, Nguyen et al. (2011) in Vietnam, Andrade et al. (2012) in Brazil, and Badouei et al. (2016) in Iran. In this study, the rate of STEC was $30.7 \%$ with a predominance in cattle calves $(45.7 \%)$ than in buffalo calves $(17.5 \%)$. This was nearly comparable to that reported by Arya et al. (2008) and Nguyen et al. (2011) who found that the rate of STEC in cattle calves was 45.55 and $51 \%$, respectively. Previous studies investigated the lower rate of STEC which was $3.3 \%$ in cattle calves (Güler et al. 2008) and $6.8 \%$ in buffalo calves (Borriello et al. 2012).

Among the STEC isolates, the rate of $s t x_{1}$ (37.3\%) was higher than that of $s t x_{2}(17.7 \%)$. Our result was in accord with Borriello et al. (2012); Dehdashti et al. (2019), and Taghadosi et al. (2018) who delineated $s t x_{1}$ predominance over $s t x_{2}$ in STEC isolates. In other studies, equal distribution of $s t x_{1}$ and $s t x_{2}$ within STEC isolates in calves had been reported (Arya et al. 2008; Nguyen et al. 2011). It is now known that calves are the reservoir of STEC in the herds (Wani et al. 2003); however, the direct pathological link/relationship between the detection of STEC isolates in calves and the health status of the calves (presence of diarrhea) is debated. While many literatures confirm the positive correlation between them where STEC prevalence was higher in diarrheic calves rather than in in-contact ones (Ok et al. 2009), other team denied this correlation and could isolate STEC from in-contact calves at a higher frequency than from diarrheic calves (Güler et al. (2008). Others could not find any differences in STEC prevalence in both calf groups (Roopnarine et al. 2007; Aref et al. 2018). Although both healthy and diarrheic calves carried STEC, it had been incriminated as a cause of calf diarrhea as detected by Sandhu and Gyles (2002) and confirmed by Coura et al. (2015) who proved that STEC acts as the sole agent in the feces of diarrheic calves.

In the present study, the astA gene was found in $20.7 \%$ of $E$. coli isolates with a higher rate in buffalo calves than in cattle calves. This result was higher than that obtained by Gharieb et al. (2015) and Yuste et al. (2006) who detected the ast $A$ gene in 14.28 and $15.6 \%$ of $E$. coli isolates, respectively. This gene was found as the sole virulence factor in $7.3 \%$ of $E$. coli isolates that are known to be enteroaggregative E. coli (EAEC). Moreover, the astA gene was reported in 5 

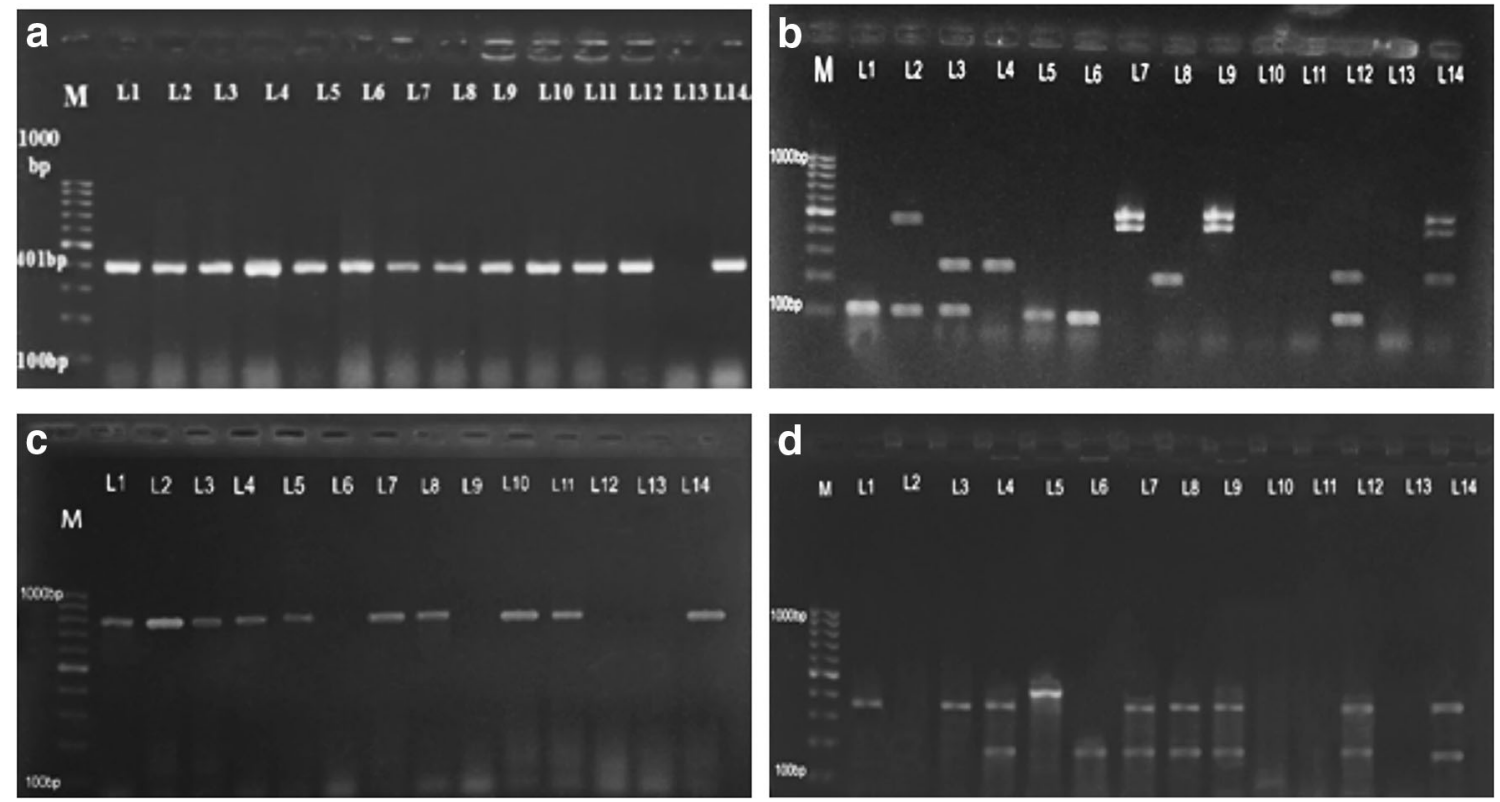

Fig. 1 a 16s rRNA gene PCR product. Lane M: 100-1000 bp. DNA marker. Lanes from 1 to 12: positive samples at $401 \mathrm{bp}$. Lanes 13 and 14 represent negative and positive control, respectively. b Multiplex PCR for detecting $s t x_{1}$, eae, hylA, and astA genes in E. coli strains. Lane M: 100-1000 bp DNA marker. Lanes 1, 5, and 6: positive samples of astA gene at $102 \mathrm{bp}$. Lane 2: positive sample of astA and eae genes at 104 and $482 \mathrm{bp}$, respectively. Lanes 3 and 12: positive samples of $a s t A$ and $s t x_{1}$ genes at 102 and $244 \mathrm{bp}$, respectively. Lanes 4 and 8: positive samples of stx $x_{1}$ gene at $244 \mathrm{bp}$. Lanes 7 and 9: positive samples of eae and hylA genes at 482 and $569 \mathrm{bp}$, respectively. Lanes 10-11: negative samples. Lane 13 represents negative control. Lane 14 represents positive control for $s t x_{l}$, eae, and hylA genes at 244, 482, and 569 bp, respectively. c Multiplex

PCR for detecting $s t x_{2}$ gene in E. coli strains. Lane M: 100-1000 bp DNA marker. Lanes $1-5,7-8$, and 10-11: positive samples of $s t x_{2}$ gene at $779 \mathrm{bp}$; lanes 6, 9, and 12: negative samples. Lanes 13 and 14 represent negative and positive control for $s_{t} x_{2}$ gene at $779 \mathrm{bp}$, respectively. d Multiplex PCR for detection of $f 5$, st, and $l t$ genes in $E$. coli strains. Lane M: 100-1000 bp DNA marker. Lanes 1 and 3: positive samples of $f 5$ gene at $314 \mathrm{bp}$. Lanes 2, 10, and 11: negative samples. Lanes 4, 7-9, and 12: positive samples of $s t$ and $f 5$ genes at 190 and $314 \mathrm{bp}$, respectively. Lane 5: positive sample of $l t$ gene at $450 \mathrm{bp}$. Lane 6: positive sample of st gene at $190 \mathrm{bp}$. Lanes 13 and 14 represent negative and positive controls for $s t$ and $f 5$ genes at 190 and $314 \mathrm{bp}$, respectively

ETEC isolates which agreed with Mahanti et al. (2014). The results also showed the presence of the astA gene in isolates from 7 STEC, 7 ETEC/STEC, and 1 EPEC isolate as mentioned by Shabana et al. (2013), Gharieb et al. (2015) and Badouei et al. (2016). This finding indicated that this gene constitutes an additional determinant in the pathogenesis of E. coli causing diarrhea in calves.

In general, the differences between the findings of $E$. coli pathotypes and their virulence genes may be attributed to the differences in geographical locations or may be due to management factors, such as overcrowding, exposure to severe environmental conditions, and insufficient intake of colostrum, which allow the opportunistic E. coli to express virulence genes causing disease in calves (Cho and Yoon 2014). The presence of pathogenic E. coli in apparently healthy contact calves in our study may be attributed to the time of sampling before calves showing diarrhea as these calves were sampled for one time. Another possible explanation may be attributed to the immunity of the animal as these calves may have a robust immune response which prevented the effect of pathogenic E. coli.

In the present study, some E. coli isolates showed mixed combinations of ETEC with STEC in 22 isolates (14.7\%) and

ETEC with EPEC in 4 isolates (2.7\%). These results agreed with previous reports that detected mixed combinations of different E. coli pathotypes (Franck et al. 1998; Ok et al. 2009; Nguyen et al. 2011; Andrade et al. 2012; Sharma et al. 2017; Aref et al. 2018). Also, Johura et al. (2017) detected that $34 \%$ of pathogenic $E$. coli isolates from different livestock were carried toxin genes of both ETEC and STEC $(s t / s t x)$ and termed them as hybrid strains. The atypical combinations may be attributed to the fact that most $E$. coli virulence genes exist on mobile genetic elements like plasmids ( $f 5$, st, and lt) and bacteriophages (stx) and can be transmitted between $E$. coli isolates through horizontal gene transfer (Andrade et al. 2012). These atypical combinations may result in the emergence of new pathotypes which may be more pathogenic and cause severe diarrhea in calves. These isolates were responsible for NCD and are considered a potential public health hazard in Egypt (Aref et al. 2018). The evolutionary history of pathogenic $E$. coli shows that STEC O157:H7 was developed from the EPEC strain O55:H7 about 500 years ago. Feng and his team (the two references in the subsequent texts) illustrated the stepwise evolutionary pathway of STEC strains from their common precursor. During this journey, the genotype and group of the strains changed via the acquisition or 
Table 4 Distribution of virulence genes profile combinations of pathogenic E. coli strains isolates from diarrheic and apparently healthy in-contact cattle and buffalo calves

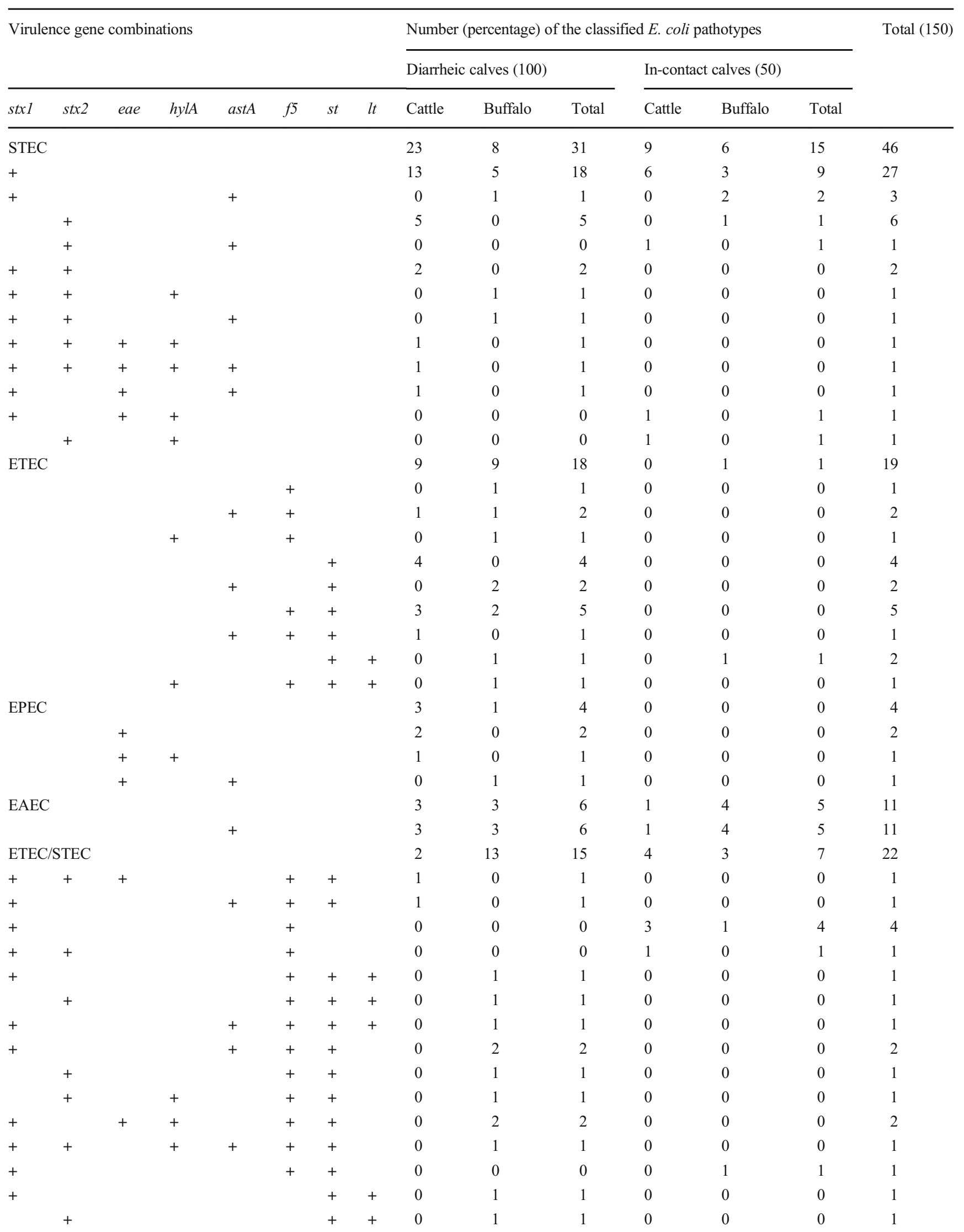


Table 4 (continued)

Virulence gene combinations

Number (percentage) of the classified E. coli pathotypes

Total (150)

Diarrheic calves (100)

In-contact calves (50)

\begin{tabular}{|c|c|c|c|c|c|c|c|c|c|c|c|c|c|c|}
\hline$s t x i$ & stx 2 & eae & hylA & ast A & f5 & st & $l t$ & Cattle & Buffalo & Total & Cattle & Buffalo & Total & \\
\hline+ & & & & + & & + & + & 0 & 0 & 0 & 0 & 1 & 1 & 1 \\
\hline+ & + & & & + & & + & + & 0 & 1 & 1 & 0 & 0 & 0 & 1 \\
\hline \multirow{5}{*}{\multicolumn{2}{|c|}{ ETEC/EPEC }} & & & & & & & 1 & 2 & 3 & 0 & 1 & 1 & 4 \\
\hline & & + & & & + & + & & 1 & 0 & 1 & 0 & 0 & 0 & 1 \\
\hline & & + & + & & + & + & & 0 & 0 & 0 & 0 & 1 & 1 & 1 \\
\hline & & + & & & & + & & 0 & 1 & 1 & 0 & 0 & 0 & 1 \\
\hline & & + & + & & & + & & 0 & 1 & 1 & 0 & 0 & 0 & 1 \\
\hline
\end{tabular}

loss of virulence genes, such as the Shiga toxin-encoding bacteriophages (stx1, stx2, stx2e, stx2f), mobility, ability to ferment sorbitol, or the acquisition of the LEE pathogenicity island (Feng et al. 2007; Zhou et al. 2010). The horizontal gene transfer via mobile genetic elements was shown to influence their pathotypes and is responsible for the continuous development of new clones. This occurs through the acquisition or loss of virulence genes which results in changing the lineage and enables the evolution of new variants with new properties and new pathogenesis (Ahmed et al. 2008).

In the present study, ETEC, EPEC, EAEC, and ETEC/ EPEC pathotypes were isolated at the highest rate from the 1 st age group (up to 4 weeks). This indicated that most pathogenic E. coli pathotypes were found at 1st weeks of life and so the neonatal calves were found to be at higher risk of $E$. coli infection. The presence of most $E$. coli pathotypes in the 1st weeks of life came in agreement with previous results (DebRoy and Maddox 2001; Andrade et al. 2012; Hossain et al. 2014) and this may be attributed to the fact mentioned by Villarroel (2009) that young neonates are more susceptible due to their naïve immune system. Also, Constable et al.
(2017) mentioned that young calves are highly susceptible, especially newborn animals that had ingested insufficient colostrum or had absorbed insufficient colostral immunoglobulins. In the present study, ETEC was surprisingly isolated from calves till 2 months old, although the first week of age is the major cause of neonatal diarrhea (Nataro and Kaper 1998). A possible explanation for the presence of ETEC in older diarrheic calves may be attributed to concurrent infection with other enteropathogens. This result came in line with Coura et al. (2015) who isolated ETEC in 30-day-old calf with concurrent infection with coronavirus.

The rate of $E$. coli infection was found to be higher in winter season than in summer, especially for STEC, EPEC, EAEC, and ETEC/EPEC. This result agreed with Sharma et al. (1984) and Shahrani et al. (2014) who recorded the highest prevalence rate of $E$. coli infection in the winter. The seasonal higher prevalence in the winter was attributed to climatic variables and the collection of calves together in a closed place which affects the immunity, making calves more prone to infections. It may also be attributed to the mean serum IgG1 concentration which was low in winter-born

Table 5 Distribution of different pathotypes of investigated E. coli strains

\begin{tabular}{|c|c|c|c|c|c|c|c|}
\hline \multirow[t]{3}{*}{ Pathotypes } & \multicolumn{6}{|c|}{ Number (percentage) of the classified $E$. coli strains } & \multirow[t]{3}{*}{ Total $(150)$} \\
\hline & \multicolumn{3}{|c|}{ Diarrheic calves (100) } & \multicolumn{3}{|c|}{ In-contact calves $(50)$} & \\
\hline & Cattle 51 & Buffalo 49 & Total 100 & Cattle 19 & Buffalo 31 & Total 50 & \\
\hline STEC & $23(45.1)$ & $8(16.3)$ & $31(31)$ & $9(47.4)$ & $6(19.3)$ & $15(0.3)$ & $46(30.7)$ \\
\hline ETEC & $9(17.7)$ & $9(18.4)$ & $18(18)$ & 0 & $1(3.2)$ & $1(0.2)$ & $19(12.7)$ \\
\hline EPEC & $3(5.9)$ & $1(2)$ & $4(4)$ & 0 & 0 & 0 & $4(2.7)$ \\
\hline EAEC & $3(5.9)$ & $3(6.1)$ & $6(6)$ & $1(5.3)$ & 4 (12.9) & $5(10)$ & $11(7.3)$ \\
\hline ETEC/STEC & $2(3.9)$ & $13(26.5)$ & $15(15)$ & $4(21.1)$ & $3(9.7)$ & $7(14)$ & $22(14.7)$ \\
\hline ETEC/EPEC & $1(1.9)$ & $2(4.1)$ & $3(3)$ & 0 & $1(3.2)$ & $1(2)$ & $4(2.7)$ \\
\hline $\mathrm{TP}$ & $41(80.4)$ & $36(73.5)$ & $77(77)$ & $14(73.7)$ & $15(48.4)$ & $29(58)$ & $106(70.7)$ \\
\hline NP & $10(19.6)$ & $13(26.5)$ & $23(23)$ & $5(26.3)$ & $16(51.6)$ & $21(42)$ & $44(29.3)$ \\
\hline
\end{tabular}


a

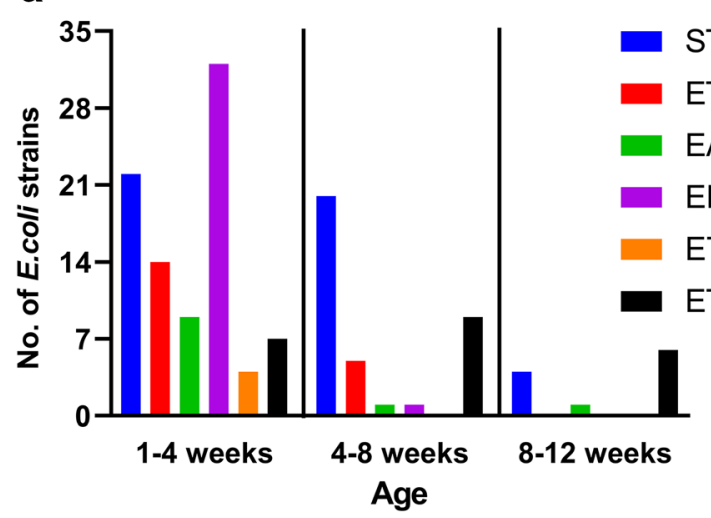

Fig. 2 a Distribution of various E. coli pathotypes strains (ETEC, STEC, EAEC, EPEC, ETEC/EPEC, and ETEC/STEC) at different age groups (up to 4 weeks, $4-8$ weeks, and 8-12 weeks). b Distribution of total and

calves and increased during the spring and summer as previously reported (Gay et al. 1983; Norheim et al. 1985). This was consistent with Snodgrass et al. (1986) who reported that the winter season affects passive colostral immunoglobulins transfer in calves. However, increased or decreased IgG1 concentrations without ascertaining their specificity to $E$. coli may not be linked to $E$. coli infections in winter, unless the increased concentrations IgG1 can be established specifically b

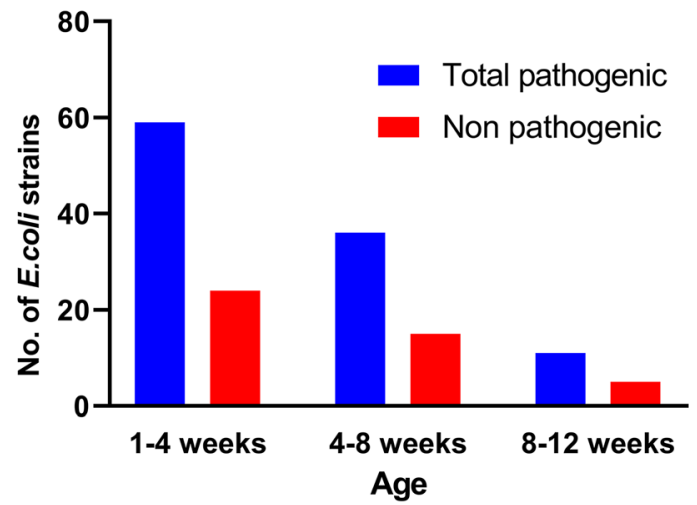

non-pathogenic $E$. coli strains at different age groups (up to 4 weeks, 4 8 weeks, and $8-12$ weeks)

to $E$. coli. No association between different $E$. coli pathotypes and animal sex was recorded. This result agreed with Pourtaghi et al. (2015) who did not find any significant correlation between sex and prevalence of pathogenic E. coli. On the other hand, it disagreed with Islam et al. (2015) and Gebregiorgis and Tessema (2016) who reported the higher infection rate in female calves in non-performed and performed statistical analysis for their results, respectively.
Fig. 3 a Distribution of total pathogenic and non-pathogenic E. coli strains at different sexes and seasons. b Distribution of different pathotypes of $E$. coli strains during winter and summer seasons and at different sexes
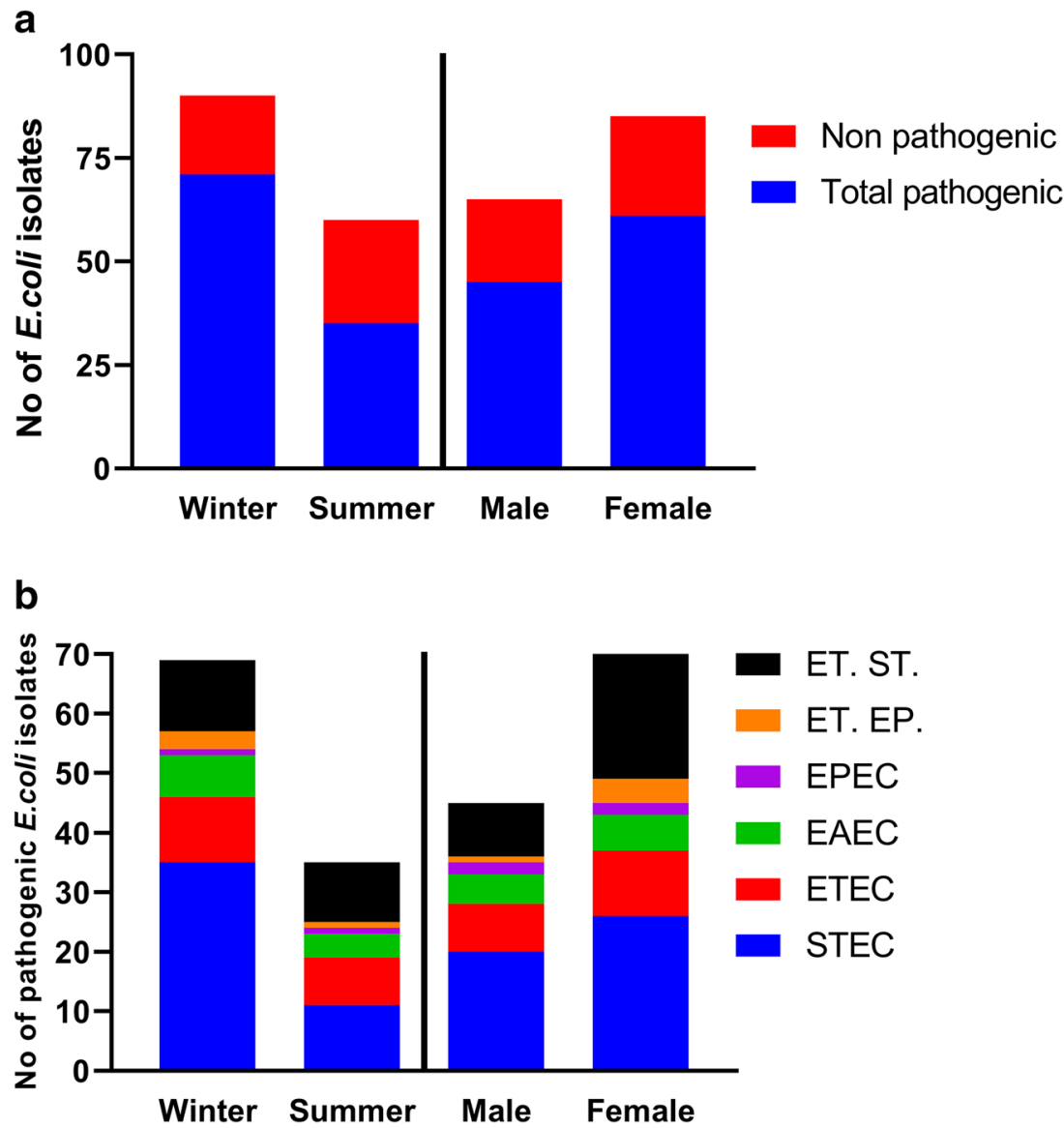


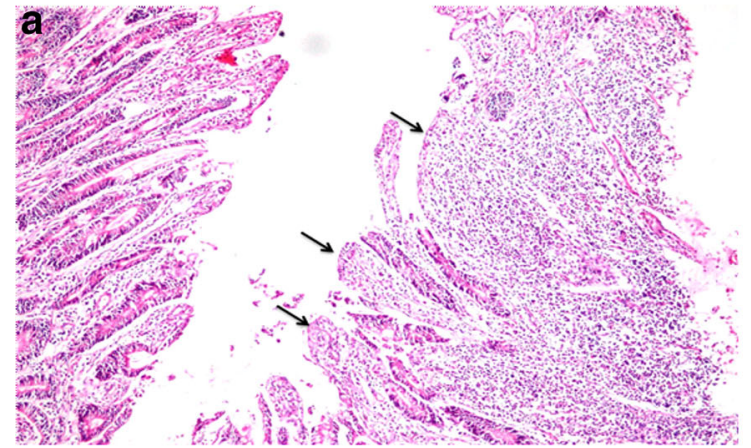

C
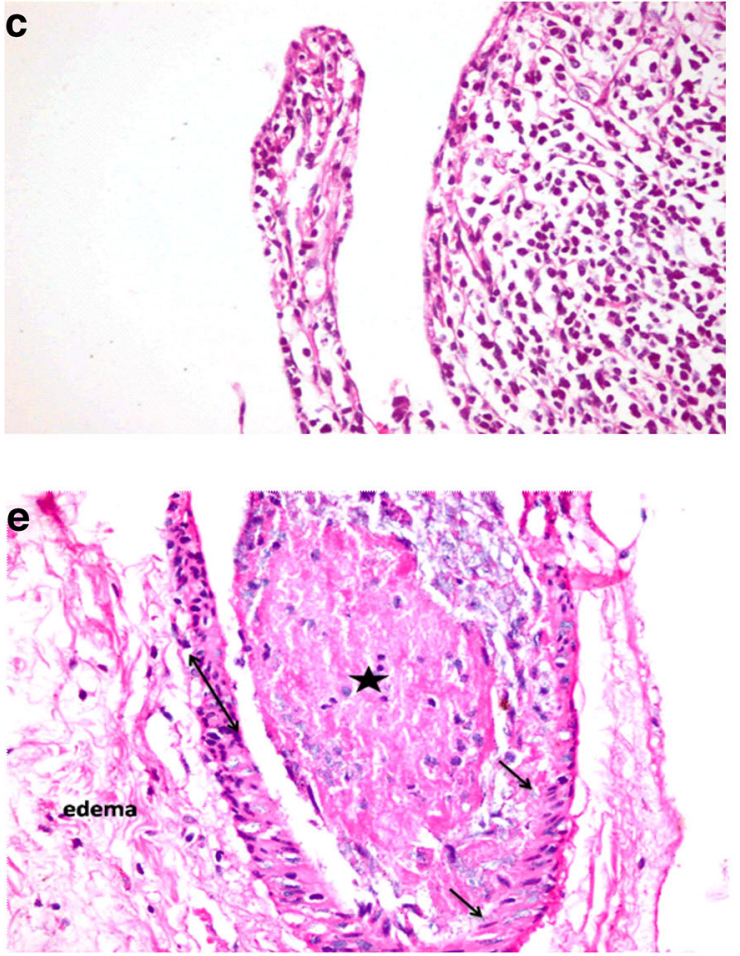

Fig. 4 a Shortening and blunting of intestinal villi (arrow) with massive destruction and inflammatory reaction of the lamina propria $(\mathrm{H} \& \mathrm{E}$, $\times 100$ ). b Fusion of small intestinal villi $(\mathrm{F})$ with shortening (double head arrow) associated with dilatation of blood capillaries (b) and intense leucocytic infiltration $(\mathrm{H} \& \mathrm{E}, \times 100)$. c Desquamation of the enterocytes lining the intestinal mucosa associated with neutrophils, macrophages, and lymphocyte infiltration in the lamina propria $(H \& E, \times 200)$. d

The correlation between the molecular characterization of E. coli isolates from intestinal samples and histopathological examination revealed the presence of eae gene encoding the intimin protein, the principal key in the E. coli $\mathrm{AE}$ effect (Nataro and Kaper 1998; Mainil and Fairbrother 2014). The absence of the $f 5$ gene from intestinal isolates was surprising, as it was claimed that F5 fimbrial antigen is the most attaching factor in neonatal calves' small intestine (Franck et al. 1998; Nagy and Fekete 2005; Foster and Smith (2009). The histopathological finding of dead calves' small intestine revealed shortening and fusion of intestinal villi and desquamation of
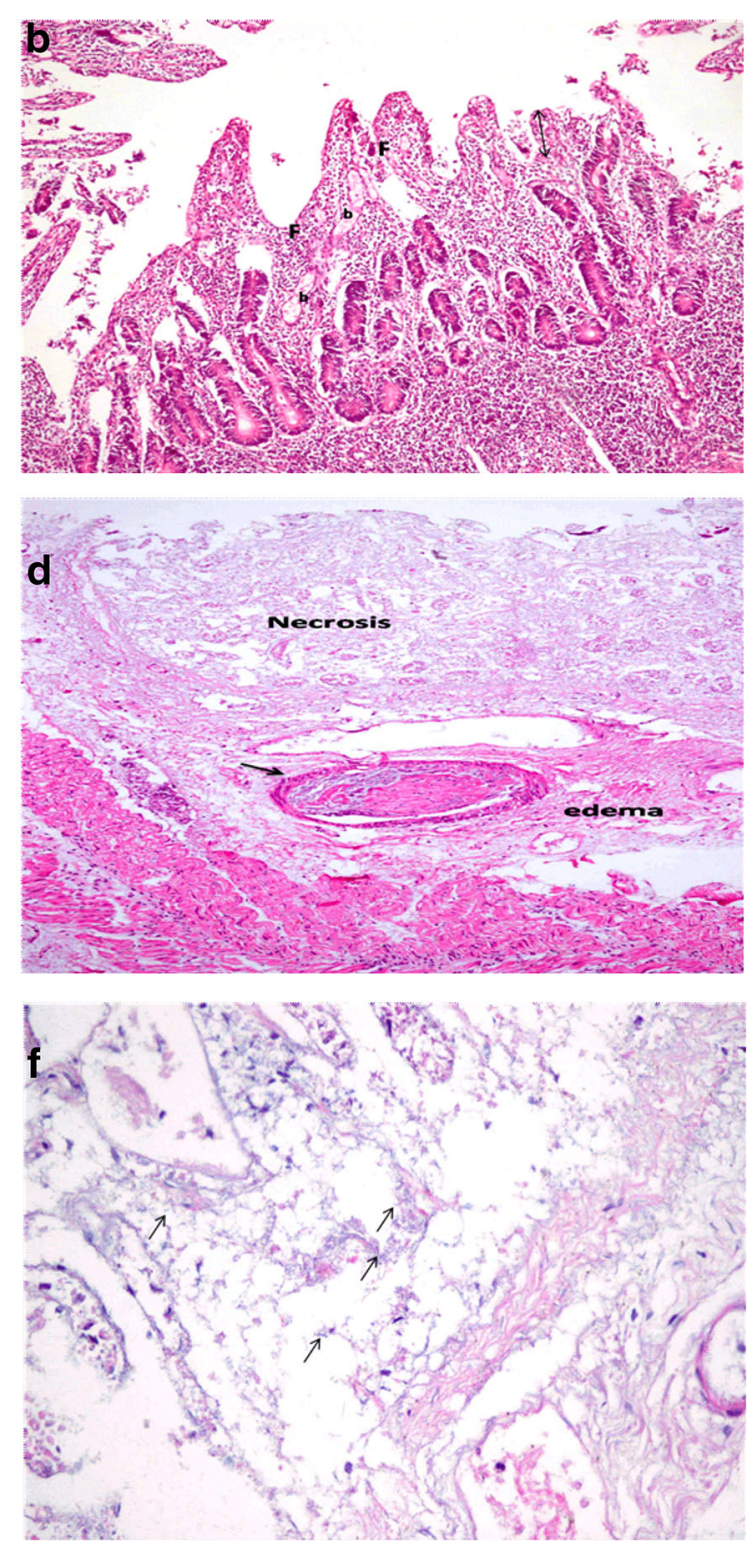

Massive necrosis of large intestinal mucosa and the associated glands with thrombosis (arrow) and extensive edema of the underlying submucosa that extending into underlying muscular layer $(\mathrm{H} \& \mathrm{E}, \times 100)$. e Thrombus formation (asterisk) attached to the injured intima (arrow) with inflammatory cells infiltrating the vascular wall associated with perivascular edema $(H \& E, \times 400)$. f Presence of small basophilic bacilli infiltrating the necrosed intestinal mucosa (arrow) (H\&E, ×400)

the lining epithelium of the intestinal mucosa. Singh et al. (2013) and Shesh et al. (2015) recorded similar histopathological lesions in the intestines of calves due to $E$. coli infection but without molecular characterization of these isolates. Actually, the histopathological lesions in the large intestine were characterized by massive necrosis of the intestinal mucosa, indicating concurrent infection with other pathogens. As the calves' diarrhea is considered a multifactorial disease, mixed infection with other bacteria, such as Clostridium spp., indicated by the presence of basophilic bacilli in the necrotic mucosa and in the lamina propria as these bacilli 
may not relate to $E$. coli. This result came in line with Garcia et al. (2013) who isolated Clostridium spp. from the intestine of calves which caused severe lesions in the colon characterized by coagulative necrosis of the intestinal mucosa.

\section{Conclusion}

In conclusion, the exploitation of different PCR assays for detecting genes encoding virulence factors helps to study the different $E$. coli pathotypes affecting diarrheic calves. The presence of atypical combinations between different pathotypes in E. coli isolates may give rise to the evolution of new pathotypes which may be more pathogenic and causing severe diarrhea in calves. Most of these atypical combinations were found more in buffalo calves than in cattle calves as ETEC/STEC combination was detected in 16 buffalo calves and only 6 cattle calves, and the ÈT/EP combination was in 3 buffalo calves and only 1 cattle calves. AstA as an additional gene was also found in 14 buffalo calves compared to only 6 cattle calves. While STEC and EPEC isolates were detected more in cattle calves than in buffalo calves, ETEC isolates were the same in the two species. This study also revealed that the pathological effect of $E$. coli on buffalo calves is mainly attributed to the eae-positive isolates which are characterized by their AE effect on the intestinal mucosa causing diarrhea. This characterization of the different pathotypes will actually help in vaccine evaluation and development for controlling E. coli-induced diarrhea which causes high economic losses and has public health hazards.

Acknowledgments This study was performed by support grants from the Faculty of Veterinary Medicine, Cairo University.

\section{Compliance with ethical standards}

Conflict of interest The authors declare that they have no conflict of interest.

Ethics declarations The study was approved and carried out in accordance with the ethics operational guidelines and the policy of the Institutional Animal Care and Use Committee (IACUC), Faculty of Veterinary Medicine, Cairo University. The ethical guidelines of IACUC were designed in accordance with the international standards.

\section{References}

Ahmed, N., Dobrindt, U., Hacker, J. and Hasnain, S. E., 2008. Genomic fluidity and pathogenic bacteria: applications in diagnostics, epidemiology and intervention. Nature Reviews Microbiology, 6(5), 387-394.

Andrade, G.I., Coura, F.M., Santos, E.L.S., Ferreira, M.G., Galinari, G.C.F., Facury Filho, E.J., Carvalho, A.U. de, Lage, A.P. and Heinemann, M.B., 2012. Identification of virulence factors by multiplex PCR in Escherichia coli isolated from calves in Minas
Gerais, Brazil. Tropical Animal Health and Production, 44, 17831790.

Aranda, K.R.S., Fagundes-Neto, U. and Scaletsky, I.C.A., 2004. Evaluation of multiplex PCRs for diagnosis of infection with diarrheagenic Escherichia coli and Shigella spp. Journal of Clinical Microbiology, 42, 5849-5853.

Aref, N.-E.M., Abdel-Raheem, A.-R.A., Kamaly, H.F. and Hussien, S.Z., 2018. Clinical and sero-molecular characterization of Escherichia coli with an emphasis on hybrid strain in healthy and diarrheic neonatal calves in Egypt. Open Veterinary Journal, 8, 351-359.

Arya, G., Roy, A., Choudhary, V., Yadav, M.M. and Joshi, C.G., 2008. Serogroups, atypical biochemical characters, colicinogeny and antibiotic resistance pattern of Shiga toxin-producing Escherichia coli isolated from diarrhoeic calves in Gujarat, India. Zoonoses Public Health, 55, 89-98.

Badouei, M.A., Morabito, S., Najafifar, A. and Mazandarani, E., 2016. Molecular characterization of enterohemorrhagic Escherichia coli hemolysin gene (EHEChlyA) harboring isolates from cattle reveals a diverse origin and hybrid diarrheagenic strains. Infection, Genetics and Evolution, 39, 342-348.

Bhat, M. A., Nishikawa, Y. and Wani, S. A., 2008. Prevalence and virulence gene profiles of Shiga toxin-producing Escherichia coli and enteropathogenic Escherichia coli from diarrhoeic and healthy lambs in India. Small Ruminant Research, 75, 65-70

Borriello, G., Lucibelli, M.G., Carlo, E. de, Auriemma, C., Cozza, D., Ascione, G., Scognamiglio, F., Iovane, G. and Galiero, G., 2012. Characterization of enterotoxigenic E. coli (ETEC), Shiga-toxin producing $E$. coli (STEC) and necrotoxigenic E. coli (NTEC) isolated from diarrhoeic Mediterranean water buffalo calves (Bubalus bubalis). Research in Veterinary Science, 93, 18-22.

Chandra, M., Cheng, P., Rondeau, G., Porwollik, S. and McClelland, M., 2013. A single step multiplex PCR for identification of six diarrheagenic E. coli pathotypes and Salmonella. International Journal of Medical Microbiology, 303, 210-216.

Cho, Y.-I. and Yoon, K.-J., 2014. An overview of calf diarrheainfectious etiology, diagnosis, and intervention. Journal of Veterinary Science, 15, 1-17.

Constable, P.D., Blood, D.C. and Radostits, O.M., 2017. Veterinary medicine: a textbook of the diseases of cattle, horses, sheep, pigs, and goats. St. Louis Missouri: Elsevier.

Coura, F.M., Freitas, M.D., Ribeiro, J., Leme, R.A. de, Souza, C. de, Alfieri, A.A., Facury Filho, E.J., Carvalho, A.Ú. de, Silva, M.X., Lage, A.P. and Heinemann, M.B., 2015. Longitudinal study of Salmonella spp., diarrheagenic Escherichia coli, rotavirus, and coronavirus isolated from healthy and diarrheic calves in a Brazilian dairy herd., Tropical Animal Health and Production, 47, 3-11.

DebRoy, C. and Maddox, C.W., 2001. Identification of virulence attributes of gastrointestinal Escherichia coli isolates of veterinary significance. Animal Health Research Reviews, 2, 129-140.

Dehdashti, S., Ghanbarpour, R. and Hajikolaei, M.R.H., 2019. Molecular detection of Shiga toxin-producing and antibiotic-resistant Escherichia coli isolates from buffaloes in southwest of Iran. Tropical Animal Health and Production, 1-12.

Fakih, I., Thiry, D., Duprez, J.N., Saulmont, M., Iguchi, A., Piérard, D., Jouant, L., Daube, G., Ogura, Y., Hayashi, T. and Taminiau, B., 2017. Identification of Shiga toxin-producing (STEC) and enteropathogenic (EPEC) Escherichia coli in diarrhoeic calves and comparative genomics of $\mathrm{O} 5$ bovine and human STEC. Veterinary Microbiology, 202,16-22

Feng, P. C., S. R. Monday, D. W. Lacher, L. Allison, A. Siitonen, C. Keys, M. Eklund, H. Nagano, H. Karch, J. Keen, and T. S. Whittam., 2007. Genetic diversity among clonal lineages within Escherichia coli O157:H7 stepwise evolutionary model. Emerging Infectious Diseases,13(11),1701-1706. 
Foster, D.M. and Smith, G.W., 2009. Pathophysiology of diarrhea in calves. Veterinary Clinics of North America: Food Animal Practice, 25, 13-36.

Franck, S.M., Bosworth, B.T. and Moon, H.W., 1998. Multiplex PCR for enterotoxigenic, attaching and effacing, and Shiga toxin-producing Escherichia coli strains from calves. Journal of Clinical Microbiology, 36, 1795-1797.

Gannon, V.P., King, R.K., Kim, J.Y. and Thomas, E.J., 1992. Rapid and sensitive method for detection of Shiga-like toxin-producing Escherichia coli in ground beef using the polymerase chain reaction. Applied and Environmental Microbiology, 58, 3809-3815.

Garcia, J.P., Anderson, M., Blanchard, P., Mete, A. and Uzal, F.A., 2013. The pathology of enterotoxemia by Clostridium perfringens type $\mathrm{C}$ in calves. Journal of Veterinary Diagnostic Investigation, $25,438-442$.

Gay, C.C., McGuire, T.C., Parish, S.M., 1983. Seasonal variation in passive transfer of immunoglobulin G1 to newborn calves. Journal of American Veterinary Medical Association, 183, 566-8.

Gebregiorgis, A. and Tessema, T.S., 2016. Characterization of Escherichia coli isolated from calf diarrhea in and around Kombolcha, South Wollo, Amhara Region, Ethiopia. Tropical Animal Health and Production, 1-9.

Ghanbarpour, R., Askari, N., Ghorbanpour, M., Tahamtan, Y., Mashayekhi, K., Afsharipour, N. and Darijani, N., 2017. Genotypic analysis of virulence genes and antimicrobial profile of diarrheagenic Escherichia coli isolated from diseased lambs in Iran. Tropical Animal Health and Production, 49, 591-597.

Gharieb, R.M., Fawzi, E.M., Attia, N.E. and Bayoumi, Y.H., 2015. Calf diarrhea in Sharkia province, Egypt: diagnosis; prevalence, virulence profiles and zoonotic potential of the causal bacterial agents. International Journal of Agriculture Science and Veterinary Medicine, 3, 71-87.

Güler, L., Gündüz, K. and Ok, U., 2008. Virulence factors and antimicrobial susceptibility of Escherichia coli isolated from calves in Turkey. Zoonoses and Public Health, 55, 249-257.

Hossain, M.K., Rahman, M., Nahar, A., Khair, A. and Alam, M.M., 2014. Isolation and identification of diarrheagenic Escherichia coli causing colibacillosis in calf in selective areas of Bangladesh. Bangladesh Journal of Veterinary Medicine, 11, 145-149.

Islam, A.K.M.A., Rahman, M., Nahar, A., Khair, A. and Alam, M.M., 2015. Investigation of pathogenic Escherichia coli from diarrheic calves in selective area of Bangladesh. Bangladesh Journal of Veterinary Medicine, 13, 45-51.

Johura, F.-T., Parveen, R., Islam, A., Sadique, A., Rahim, M.N., Monira, S., Khan, A.R., Ahsan, S., Ohnishi, M. and Watanabe, H., 2017. Occurrence of hybrid Escherichia coli strains carrying Shiga toxin and heat-stable toxin in livestock of Bangladesh. Frontiers in Public Health, 4, 287.

Kamel, M., El-Hassan, D.G.A. and El-Sayed, A., 2015. Epidemiological studies on Escherichia coli O157:H7 in Egyptian sheep. Tropical Animal Health and Production, 47, 1161-1167.

Law, D., 2000. Virulence factors of Escherichia coli O157 and other Shiga toxin-producing E. coli. Journal of Applied Microbiol, 88, 729-745.

Luna, L.G., 1968. Manual of histologic staining methods of the Armed Forces Institute of Pathology. 3rd Ed., McGraw Hill Book Company, New York.

Mahanti, A., Samanta, I., Bandyopadhyay, S., Joardar, S.N., Dutta, T.K. and Sar, T.K., 2014. Isolation, molecular characterization and antibiotic resistance of enterotoxigenic E. coli (ETEC) and necrotoxigenic $E$. coli (NTEC) from healthy water buffalo. Veterinarski arhiv, 84,241-50.

Mainil, J. and Fairbrother, J., 2014. Escherichia coli in domestic mammals and birds. Pathogenic Escherichia coli: molecular and cellular microbiology, chapter 2.
Manzoor, R., Shah, M.I., Wani, S.A., Pandit, F., Dar, P.A. and Mir, M.I., 2015. Prevalence, serodiversity and antibiogram of enterotoxigenic Escherichia coli (ETEC) in diarrhoeic calves and lambs of Kashmir valley (J\&K), Indian Journal of Applied and Natural Science, 7, 477-481.

Moxley, R.A. and Smith, D.R., 2010. Attaching-effacing Escherichia coli infections in cattle. Veterinary Clinics: Food Animal Practice, 26, 29-56.

Müller, D., Greune, L., Heusipp, G., Karch, H., Fruth, A., Tschäpe, H. and Schmidt, M.A., 2007. Identification of unconventional intestinal pathogenic Escherichia coli isolates expressing intermediate virulence factor profiles by using a novel single-step multiplex PCR. Applied and Environmental Microbiology, 73, 3380-3390.

Nagy, B. and Fekete, P.Z., 2005. Enterotoxigenic Escherichia coli in veterinary medicine. International Journal of Medical Microbiology, 295, 443-454.

Nataro, J.P. and Kaper, J.B., 1998. Diarrheagenic Escherichia coli. Clinical Microbiology Reviews, 11, 142-201.

Nguyen, T.D., Vo, T.T. and Vu-Khac, H., 2011. Virulence factors in Escherichia coli isolated from calves with diarrhea in Vietnam. Journal of Veterinary Science, 12, 159-164.

Norheim, K., Simensen, E. and Gjestang, K.E., 1985. The relationship between serum IgG levels and age, leg injuries, infections and weight gains in dairy calves. Nordisk Veterinaer Medicin, 37, 113-20.

Ok, M., Güler, L., Turgut, K., Ok, U., Sen, I., Gündüz, I.K., Birdane, M.F. and Güzelbekteș, H., 2009. The studies on the aetiology of diarrhoea in neonatal calves and determination of virulence gene markers of Escherichia coli strains by multiplex PCR. Zoonoses and Public Health, 56, 94-101.

Osman, K.M., Mustafa, A.M., Elhariri, M. and Abdelhamed, G.S., 2013. The distribution of Escherichia coli serovars, virulence genes, gene association and combinations and virulence genes encoding serotypes in pathogenic E. coli recovered from diarrhoeic calves, sheep and goat. Transboundary and Emerging Diseases, 60, 69-78.

Piérard, D., De Greve, H., Haesebrouck, F. and Mainil, J., 2012. O157: H7 and O104: H4 Vero/Shiga toxin-producing Escherichia coli outbreaks: respective role of cattle and humans. Veterinary Research, 43,13

Pourtaghi, H., Ghaznavi, S., Sodagari, H.R. and Ghadimianazar, A., 2015. Detection of enterotoxigenic Escherichia coli isolated from calves' diarrhoea samples by molecular and serological methods. Advanced Studies in Biology, 7, 293-300.

Radostits, O.M., Gay, C.C., Hinchcliff, K.W. and Constable, P.D., 2007. Veterinary medicine: a textbook of the diseases of cattle, sheep, pigs, goats and horses, Saunders, London.

Roopnarine, R.R., Ammons, D., Rampersad, J. and Adesiyun, A.A., 2007. Occurrence and characterization of verocytotoxigenic Escherichia coli (VTEC) strains from dairy farms in Trinidad. Zoonoses and Public Health, 54, 78-85.

Sandhu, K.S. and Gyles, C.L., 2002. Pathogenic Shiga toxin-producing Escherichia coli in the intestine of calves. Canadian Journal of Veterinary Research, 66, 65-72.

Shabana, I.I., Algammal, A.M. and Suzuki, H., 2013. Molecular typing of the enteroaggregative $E$. coli heat-stable enterotoxin 1 gene (EAST1) in E. coli strains isolated from human and calves with diarrhea. Global Animal Science Journal, 1, 38-44.

Shahrani, M., Dehkordi, F.S. and Momtaz, H., 2014. Characterization of Escherichia coli virulence genes, pathotypes and antibiotic resistance properties in diarrheic calves in Iran. Biological Research, 47, 28-40.

Sharma, M.C., Pathak, N.N., Hung, N.N., Lien, N.H. and Vuc, N.V., 1984. Mortality in growing Murrah buffalo calves in Vietnam. Indian Journal of Animal Science, 54, 998-1000.

Sharma, R.K., Taku, A.K., Malik, A., Bhat, M.A., Javed, R., Badroo, G.A. and Kour, A., 2017. Molecular characterization and 
antimicrobial profiling of Escherichia coli isolates from diarrheic calves. Indian Journal of Animal Sciences, 87, 1467-1471.

Shesh, A., Rani, S., Dadhich, H., Joshi, A. and Sharma, S., 2015. Incidence and histopathological observations of colibacillosis in intestine of buffalo calves. Indian Journal of Veterinary Sciences and Biotechnology, 11(2),28-30.

Singh, K., Mishra, S.K., Jakhar, K.K. and Lather, D., 2013. Pathological investigation on buffalo calves suffering from gastrointestinal tract disorders. Haryana Veterinarian, 52, 38-42.

Snodgrass, D.R., Terzolo, H.R., Campbell, D., Sherwood, I., Menzies, J.D. and Synge, B.A., 1986. Aetiology of diarrhea in young calves. Veterinary Record, 119, 31-4.

Stacy-Phipps, S., Mecca, J.J. and Weiss, J.B., 1995. Multiplex PCR assay and simple preparation method for stool specimens detect enterotoxigenic Escherichia coli DNA during course of infection. Journal of Clinical Microbiology, 33, 1054-1059.

Taghadosi, R., Shakibaie, M.R., Alizade, H., Hosseini-Nave, H., Askari, A. and Ghanbarpour, R., 2018. Serogroups, subtypes and virulence factors of Shiga toxin-producing Escherichia coli isolated from human, calves and goats in Kerman, Iran. Gastroenterol Hepatol Bed Bench, 11(1), 60-67

Thiry, D., Saulmont, M., Takaki, S., Rauw, K. de, Duprez, J.N., Iguchi, A., Piérard, D. and Mainil, J.G., 2017. Enteropathogenic Escherichia coli O80:H2 in young calves with diarrhea, Belgium. Emerging Infectious Diseases, 23, 2093-2095.

Vidal, M., Kruger, E., Durán, C., Lagos, R., Levine, M., Prado, V., Toro, C. and Vidal, R., 2005. Single multiplex PCR assay to identify simultaneously the six categories of diarrheagenic Escherichia coli associated with enteric infections. Journal of Clinical Microbiology, $43,5362-5365$.
Villarroel, A., 2009. Scours in beef calves: causes and treatments, (Retrieved on May, 2013 from URL http://whatcom.wsu.edu/ag/ documents/beef/ScoursBeefCalves_OSUem8977-e.pdf)

Wang, G., Clark, C.G. and Rodgers, F.G., 2002. Detection in Escherichia coli of the genes encoding the major virulence factors, the genes defining the O157:H7 serotype, and components of the type 2 Shiga toxin family by multiplex PCR. Journal of Clinical Microbiology, 40, 3613-3619.

Wani, S.A., Bhat, M.A., Samanta, I., Nishikawa, Y. and Buchh, A.S., 2003. Isolation and characterization of Shiga toxin-producing Escherichia coli (STEC) and enteropathogenic Escherichia coli (EPEC) from calves and lambs with diarrhoea in India. Letters in Applied Microbiology, 37, 121-126.

Welch, R.A., 2006. The genus Escherichia, prokaryotes. New York, NY. 6, 60-71

Woodward, M.J. and Wray, C., 1990. Nine DNA probes for detection of toxin and adhesin genes in Escherichia coli isolated from diarrhoeal disease in animals. Veterinary Microbiology, 25, 55-65.

Yuste, M., De La Funte, R., Ruiz-Santa-Quiteria, J.A., Cid, D. and Orden, J.A., 2006. Detection of the astA (EAST1) gene in attaching and effacing Escherichia coli from ruminants. Journal of Veterinary Medicine. Series B, Infectious Diseases and Veterinary Public Health, 53, 75-77.

Zhou, Z., X. Li, B. Liu, L. Beutin, J. Xu, Y. Ren, L. Feng, R. Lan, P. R. Reeves, and L. Wang., 2010. Derivation of Escherichia coli O157: $\mathrm{H} 7$ from its $\mathrm{O} 55: \mathrm{H} 7$ precursor. PLoS One, 5(1)

Publisher's note Springer Nature remains neutral with regard to jurisdictional claims in published maps and institutional affiliations. 